Discussion Paper Series A No.546

\title{
Japan's Civil Registration Systems Before and After the Meiji Restoration
}

\author{
Osamu Saito \\ (Emeritus, Hitotsubashi University) \\ and \\ Masahiro Sato \\ (Hitotsubashi University)
}

January 2011

Institute of Economic Research

Hitotsubashi University

Kunitachi, Tokyo, 186-8603 Japan 


\title{
Paper presented at the Workshop on the Comparative History of Civil Registration, Panel 3 St John's College, Cambridge \\ 7-10 September 2010
}

Japan's civil registration systems before and after the Meiji Restoration

Osamu Saito* and Masahiro Sato ${ }^{\dagger}$

\begin{abstract}
This essay traces the evolution of Japan's systems of household and land registration from Tokugawa times to the period of early Meiji reforms in the 1870s and 80s. The paper pays due attention to the distinction between an early modern system designed by state authority and local forms of registration practice. Thus, in the section on the Tokugawa period, one such local practice of having people 'disowned' and its consequence, registerlessness, will be examined. The section on the Meiji reforms turns to the issue of continuity and discontinuity, while the next section discusses if any progress in terms of civil identity registration was made by these Meiji reforms. In order to illustrate the actual changes that took place at the local level, the essay begins with an eighteenth-century story about a peasant woman and her disputes with the village officialdom and ends with a case of family dispute that another village woman brought before court some 120 years later.
\end{abstract}

\footnotetext{
*Professor Emeritus, Hitotsubashi University. E-mail: O-Saito@ier.hit-u.ac.jp.

${ }^{\dagger}$ Professor in the Research Centre for Information and Statistics of Social Science, Hitotsubashi University. E-mail: Satow@ier.hit-u.ac.jp.
} 


\section{Prologue}

On 8 February 1763, a 44-year-old poor peasant woman named Ken refused to affix her seal to that year's population register. Herman Ooms' intriguing account of Ken's life-long struggle for justice begins with this unusual incident in Makibuse village of Shinano province. ${ }^{1}$ The story involves a case of disinheritance and the subsequent murder of her disinherited brother, both of which had happened 21 years before the population register incident; in a later stage a petition was made by her, which amounted to accusations directed at her uncle and village officials in relation to the murder case, but at the same time was seeking some sort of justice for that crime committed 17 years earlier. The refusal to certify her household's entry in the register, therefore, was a manifestation of her anger and resentment that such justice had not been done yet. Her misbehaved, gambling and drunken brother was disowned by the mother, under "the will of the lineage' and, presumably, under the pressure from village officials as well, and subsequently intra-lineage quarrels led to his violent death, beaten up by his uncle and fellow villagers. We learn from Ooms' expositions and interpretations of Tokugawa legal code and practice that one possible factor why the 'murder' was regarded as justifiable and it was Ken who bore the brunt of criticism was the fact that he had been disowned by the parent since under Tokugawa law it meant for the disowned to become an outlaw, by removing his name from the household register. We also learn that following her brother's death, her mother's eventual death, and her third husband's disappearance, Ken lived alone in her house; she was the head of the household in 1763.

This brief account of a series of rather unusual events that took place in a small village some 250 years ago suggests how eighteenth-century Japan's civil registration system worked and how different it was from the one introduced after the Meiji Restoration of 1868. This paper traces the evolution of systems of household and land registration from Tokugawa times to the period of early Meiji reforms in the 1870s and 80s, in an age in which markets in land and labour was expanding - slowly in the beginning, then acceleratingly towards the end of the period. ${ }^{2}$ The tie between family and land was the building bloc of a society in which as many as 80 per cent of the population were classified as 'peasants'. Then the section on the new Meiji state's reform efforts

\footnotetext{
${ }^{1}$ Ooms, Tokugawa village practice, ch.1: "Mountains of resentment": one woman's struggle against Tokugawa authority'. His narrative draws largely on Ozaki's Japanese-language article, 'Kenjo ikken'.

${ }^{2}$ For relationships between Tokugawa Japan's peasant household economy and the factor markets, see Saito, 'Land, labour and market forces'.
} 
turns to the issue of continuity and discontinuity, and the next section discusses if any progress was made by the Meiji reforms with respect to civil identity registration. The paper ends with an account of another dispute which was brought before court some 120 years later in a different province. Though less eventful than in Ken's case, this Meiji case too involved a peasant woman and an attempted disinheritance. The 1880 story will, it is hoped, illustrate the changes that took place at the village level in the Tokugawa-Meiji transition.

\section{Tokugawa registration practice}

When Japan introduced China's ancient state model in the seventh century, the package included a household registration system. This ancient experiment failed, however. It was not until the late sixteenth century that the renewed initiative was made. The period marked the end of a centurylong era of warring states and, not surprisingly, the unifiers wanted to know more about the people and their land that came under their rule. Thus, the early modern concept of 'registration' started as a state project. As we will see below, however, this should not be taken to imply that the early modern systems of registration worked only from above.

\section{Land registration}

Japan's early modern regime began with cadastral surveys. The series of surveys was undertaken from the end of the sixteenth century onwards by the successive unifiers, i.e. Oda Nobunaga, Toyotomi Hideyoshi and Tokugawa Ieyasu. Their project of surveying was expected to serve as a means to separate samurai, professional warriors who late became sedentary civil servants, from peasants, a class devoted — supposedly — entirely to agriculture, to facilitate the collection of taxes from the peasant class, and to tighten control over 300 daimyo (overlords) and the assignment of fiefs to them. In addition to these aims, the overlords themselves were interested in curbing geographical mobility of their own peasants; for them land and peasants was their power base, in both a fiscal and a military sense. Inevitably the whole process of surveying land and peasants was prolonged, but is said to have completed nearly everywhere by the end of the $1610 \mathrm{~s}$. Some overlords made second surveys later, tying to get hold of newly reclamated areas of farmland.

While these early measures were not rigorous enough as population surveys, the cadastral surveying processes provided detailed information about man-property relationships - the compilation of land registers determined who worked which piece of land in every village. The villagers who had to pay the land tax were those whose names were recorded in the land register. 
However, the overlord's government did not levy the tax on an individual basis. Everywhere, it was the village community's responsibility to pay all the taxes levied collectively on the villagers' land; thus, the village had to pay the sum of all those taxes even when one or two failed to bring their shares in. As a result of this peculiar system of taxation (called murauke), while the overlord held the ultimate ownership of the entire territory, the individual peasants gained the right to use an individual plot of land in an exclusive manner and also the de facto right of disposal of that land. Under Tokugawa law, it is true that the 'perpetual sale' of cultivated land was prohibited. In practice, however, sales did take place, often taking 'the form of a pledge irredeemable after ten years', although the length of years was in many cases a matter of mutual arrangement. On the other hand, the village community held a discretionary power in the land transaction process. Thus every transaction involved both the seller's relatives, who countersealed the document, and the village officials, whose function was to 'affix an official seal and change the names in the land register'. ${ }^{3}$ As a matter of fact, there existed more openly 'perpetual' sales of cultivated land. In such cases, the headman may not have affixed his official seal; yet, as a report of Mikawa province's Nukata district suggests, he was 'usually privy to it'. ${ }^{4}$ The land registers and other related documents were thus kept by village officials, never by samurai magistrates, suggesting that land registration during the Tokugawa period was administered almost exclusively by the village community.

In Ken's case land registration did not play an important part, which is rather unusual as a civil dispute between Tokugawa villagers. This is probably because Ken's family possessed only a miniscule amount of land. At the end of 1740 her family's holdings were only $0.19 \mathrm{koku}$; at the start of 1727 the figure had been $1.97 \mathrm{koku}$, even with which no family of four could make a living without extra earnings from non-farm by-employments. ${ }^{5}$ And it was for this reason that Ken's brother got involved in horse trading, which was not regarded as a steady job in the Tokugawa agrarian world, but it was this shady trade which eventually led him to a quarrel with his uncle, and hence to his violent death. However, as Ooms notes, their family had been a prominent, core member of the village; and over the period towards the early eighteenth century, they lost their properties one by one, presumably in the form of foreclosure of the mortgaged land. Thus land holdings did change the hand and every change was registered at the village office. Indeed, it was the village community that kept lists of all plots of cultivated land, and the names

\footnotetext{
${ }^{3}$ Wigmore, Law and justice, pt ii, p.11. For the publication of this data collection, see n.11 below.

${ }^{4}$ Wigmore, Law and justice, pt ii, p.18.

${ }^{5}$ Ooms, Tokugawa village practice, p.50. Koku is a capacity measure used for rice. Under Tokugawa rule every piece of land was assessed in terms of yields in rice-equivalents, and those days it was widely recognised that one koku of yields would be enough to feed an adult for a year.
} 
of holders of the fields concerned and the titles thus certified, since any change in the hand had tax implications. Because of this, and also because of the absence of an independent institutional arrangement that could handle inter-village disputes, the village authorities tried hard to keep market transactions in land within the village. In the administration of land registration too, there was a tendency that the concepts of registration and entitlement did not easily go beyond the village boundary.

\section{Household registration}

The Tokugawa system of household registration started later in the seventeenth century as a religious survey (shümon aratame). Following the decision to cut ties with the Jesuits, the Tokugawa shogunate government ordered all overlords in 1665 to take a religious census. In every village the officials drew up a new list of households and their members for inspection by the head of each household and the head priest of the respective temple; both affixed the seals to the compiled register, certifying that they were not the believers of prohibited Christianity. ${ }^{6}$

However, since the registration became annual from 1671 onwards, the compilation eventually gained an additional function of keeping a register of households and population. Figure 1 is a sample page from a typical shümon register. It lists the name and age of the head of the list, his religious affiliation and related information, the wife's age and religious information (if different), the children's name, sex and age, and finally the totals for that household (for names only first names were given, which was a Tokugawa practice). Note that the term 'head of the household' $(k o s h u)$ is not given, and that the name of the wife is omitted here. The latter cannot be taken to imply that women's position was weak in the peasant family, for, as Ken of Makibuse indicates, peasant women sometimes behaved differently from what samurai-adopted Confucian teachings told. ${ }^{7}$ On the other hand, the former is probably a reflection of rural Tokugawa practice since studies of Meiji family law have made it clear that the authority of male headship was strengthened during the Meiji period. In village customary practice, while the head was customarily a male, it did not mean that, as we will see below, women were legally excluded from the succession to headship, nor did it imply that the male head could act against interests of the corporate entity of the family (called ' $i e$ ').

\section{[Table 1]}

\footnotetext{
${ }^{6}$ Cornell and Hayami, 'Shūmon aratame chō', and Hayami, Historical demography, pp.26-37.

${ }^{7}$ Walthall, 'Life cycle', p.60.
} 
Every year in every village in the country, two registers were prepared: the original was filed in an office of the samurai magistrate in charge while the duplicate remained with the village headman, implying that all the information contained in the register remained within the village. Moreover, once in every six years, the aggregate results were reported to the shogunate government. In other words, a religious survey that had started to stamp Christians out now took two new functions: the government's undertaking of periodical censuses and local administrations' record keeping.

It is the village office that administered all the registration procedures, kept the records and used them for any administrative purpose when necessary. There were altogether more than 60,000 villages, and each was administered by a group of about ten officials. They were capable of reading and drafting these as well as other formal documents in an almost identical style (called oiery $\bar{u}$ ), which was accepted by both samurai and commoners across the country. Formal and informal schooling brought this style to children of many well-to-do peasants, so that one may say that 'there was no great difference, in terms of literacy, between peasant officialdom and samurai'. ${ }^{8}$ Villagers, on the other hand, were entitled to make requests to the village office with respect to any matters of their members' civil status and registration. Some were not literate, as was in Ken's case. But Ken had apparently no difficulty to find one who was able to draft a formal request on her behalf, ${ }^{9}$ suggesting that the general level of literacy among peasants was not low even in the mid-eighteenth century. Indeed, according to one estimate, 43 per cent of boys and 10 per cent of girls - the vast majority of whom were peasant children - acquired some form of basic literacy at school by the end of the Tokugawa period. ${ }^{10}$

However, this should not be taken to imply that a national system of the registration of demographic events came into existence. According to Zenkoku minji kanrei ruishū, compiled and published by the newly established Ministry of Justice in 1880, and translated into English later as Law and justice in Tokugawa Japan, ${ }^{11}$ the ways in which demographic events such as birth, marriage and death were registered varied from place to place. As for the registration of birth, for example, the 1880 ruish $\bar{u}$ reveals that while in most cases the report was made to the village office, either orally or in writing, there were areas where it was to the parish temple or

\footnotetext{
${ }^{8}$ Moriya, 'Urban networks', p.118. For the range of tasks the village officials did, see Sato, 'Tokugawa villages', pp.53-55, 61-62.

${ }^{9}$ Ooms, Tokugawa village practice, pp.40-41.

${ }^{10}$ Dore, Education, pp.317-322.

${ }^{11}$ The publication of John Henry Wigmore's translation of the ruish $\bar{u}$ started in 1892 as contributions to the Transactions of the Asiatic Society of Japan, but did not finish in his lifetime. The more comprehensive edition was published after World War II by the University of Tokyo Press.
} 
neighbours only. There were some other variations: for example, in Abe and Udo districts of Suruga province, 'births are reported to the village office, but not registered. Those above ten years of age are annually entered in the official register, and only once in every seven years those below ten years of age are registered'; in Moda district of Kazusa province, 'births must be reported immediately ..., but children below seven are usually excluded from the register'. There existed cases in where even conception was required to report to the village office, although as noted for Miyagi of Rikuzen province, 'the majority of people do not observe this rule because of the trouble of writing'; and in a couple of districts of Chikuzen province, despite seemingly thorough supervision of 'births and nurture of infants' by 'special officers', 'the child presents himself at the religious survey' only at seven years of age. ${ }^{12}$ It is likely that there were greater regional variations with respect to the registration of death, marriage and adoption. Indeed, although the 1880 volume simply notes that the procedures of registration were 'similar to those of births', it is recorded that in the same district of Ise as mentioned above, 'Cases of death, marriage, adoption, etc. are not reported immediately, such changes of family members being all registered at the time of the religious survey'. ${ }^{13}$ All this suggests that the timing of registration varied considerably from place to place. On the other hand, however, there is no hint in the 1880 ruish $\bar{u}$ that Tokugawa Japan's identity registration was not compulsory. Everybody in the village entered the register; the only exception was a small child who died early-in some exceptional cases, before the child reached seven years of age, but in most cases, before the next year's household and population register was compiled. To put it differently, the Tokugawa system of civil registration was fairly universal as for the commoners; the only problem lay in the area of vital registration.

In early years of Tokugawa rule, after a series of famines and peasant disturbances in the 1630s and 40s in particular, the shogunate government was preoccupied with the question of how to cope with village affairs. They produced a body of regulatory edicts and ordinances, according to which peasants were subjected to many restrictions on, for example, their own mobility. They were discouraged to leave the village to work elsewhere, to work land outside the village, and to move the household out of the village. ${ }^{14}$ This may be taken to suggest that the implementation of the religious (shümon) registration system in the subsequent decades was in fact to take control of people's whereabouts across the country, and hence that it must have been effective to tie the peasants on the land. However, Ken's story indicates that both her father and brother had

\footnotetext{
${ }^{12}$ Wigmore, Law and justice, pt vii, pp.15, 17, 19, 20, 30.

${ }^{13}$ Wigmore, Law and justice, pt vii, pp.45, 108, 225. The Ise report is on p.17.

14 Totman, Early modern Japan, pp.111-113.
} 
experiences to go to Edo for work, in the father's case for two years and in the brother's for five years. Temporal or seasonal migration was thus not uncommon, and in most cases out-migrants did not bother to notify the leave to the village office. Ken too tried to move the house formally out of the village in the later stage of her long battle with the village authorities. A cursory look at standard registration practice reveals that there existed a built-in procedure within the registration system: 'If a tradesman wishes to transfer to another province, a notification must be made to the local office, which issues a transfer certificate, and permits the applicant to leave the place. Framers, however, cannot leave unless they have appointed an heir, as they must pay landtaxes'. ${ }^{15}$ The general rule, in other words, was that 'a person may remove and transfer his registration quite freely, if he notifies the local office and obtains the transfer certificate'. ${ }^{16}$ This formal procedure enabled a non-heir son who established himself as an apprenticed tradesman or craftsman, or a branch household elsewhere, to move the residence legally. On the other hand, the rule implies that the system allowed village authorities to regulate people's movement. It explains not only why actual procedures varied from district to district, but also the reason why peasants 'cannot leave unless they have appointed an heir': since the total amount of land taxes were fixed for a village with the tax unit being the household, any change in the number of household in the village would affect everybody's tax payment, as a result of which the village officials were far more concerned with the movement of a household than with that of an individual. ${ }^{17}$ All this meant that while the Tokugawa system of identity registration was universal in the sense that no one would be administratively invisible as long as he or she was a commoner, the village boundary mattered in relation to his or her own mobility.

However, there was an exception to these rules. As suggested above with respect to the disinheritance case of Ken's brother, the removal of one's name as a member of a particular household from the village's population register meant a loss of civil protection in Tokugawa society. Tokugawa civil code and practice allowed the head of the family to 'disown' a child: 'If a son or a younger brother misconducts himself and does not obey the admonition of the father or the elder brother, the latter may report the circumstances to the local office and he is reprimanded at the office. If he still does not reform, generally an application for disowning is made, and the authorities inquire into the circumstances, and if they decide that there is no probability of his

\footnotetext{
${ }^{15}$ Wigmore, Law and justice, pt vii, p.181.

${ }^{16}$ Wigmore, Law and justice, pt vii, p.185. An entry for Katori district of Shimōsa province.

${ }^{17}$ Saito, 'Land, labour and market forces', p.185.
} 
reformation, they grant the application and remove his name from the register' ${ }^{18}$ The act of disowning was called kyüri or kandō, the former meaning 'long separation' and the latter 'to consider the appropriate punishment'. ${ }^{19}$ This usage of words implies two things. One implication is that disowning a child was - to borrow the phrase by Ooms - a 'punishment' by the family and the community and also a 'protection against possible prosecution of his or her relatives and kumi [i.e. neighbourhood group] members for crimes he or she might commit' ${ }^{20}$ Also implied is that after denied the place in the village community the disowned could not obtain a certificate of transfer, either. Thus, the removal from the register (chō-hazure) meant that the disowned too lost all kinds of 'protection' he or she could expect from the community. As the report from Izu province's Tagata district notes, the disowned became 'a vagrant' in most cases. ${ }^{21}$ Moreover, it is reported that in the Shiga district of Ōmi province "when a [registerless] person ... returns without permission, the hinin watchman is ordered to drive him away'. ${ }^{22}$ In other words, the disowned were outlaws.

It is probably because of this grave consequence that not just relatives but also village authorities were involved in the procedures of a disowning case, and as a matter of fact, many authorities seem to have tried to avoid such a Draconian consequence. Indeed, there were cases where the name of the disowned was not removed from the register but was just tagged or put in an appendix, ${ }^{23}$ or not removed unless he committed a crime twice. ${ }^{24}$ Moreover, the authorities were pleased to 'allow his name to be re-entered in the register' as soon as an application was made by the family on the grounds that he was 'reformed'. ${ }^{25}$ On the other hand, the rules were such that there were always a sizeable number of the disowned.

They were joined by another type of registerless people. A chapter on absconding in the 1880 ruish $\bar{u}$ shows that when a person absconded, a two-stage search was made with six months between the stages. 'After a lapse of a year [from the second search order], or sometimes three

\footnotetext{
${ }^{18}$ Wigmore, Law and justice, pt vii, pp.211-212. Precisely speaking, the right of the head of the family is different from the parental right. For example, the report from Abe and Udo districts of Suruga province uses the former term (p.214) while that from Aki province's Aki district speaks of the latter (p.220).

${ }^{19}$ Wigmore, Law and justice, pt vii, p.211, n.7.

${ }^{20}$ Ooms, Tokugawa village practice, $\mathrm{p} .44$.

${ }^{21}$ Wigmore, Law and justice, pt vii, p.215.

${ }^{22}$ Wigmore, Law and justice, pt vii, p.216. The 'hinin watchman' was an outcast person employed by the village community. There were many areas around Kyoto and Osaka where outcasts were involved in police work. Ōmi was one such area (p.7).

${ }^{23}$ This is found for example in Ōmi, Shimōsa, Hitachi and Sanuki provinces. Wigmore, Law and justice, pt vii, pp.215, 216, 220-221.

${ }^{24}$ This is the Tōtōmi case. See Wigmore, Law and justice, pt vii, p.214.

${ }^{25}$ See for example the Kii case in Wigmore, Law and justice, pt vii, p.220.
} 
years, the absconder's name is removed from the register' ${ }^{26}$ Seasonal and short-term outmigration without notification to the village office was tolerated on the assumption that they would eventually come home. In actuality, however, there were a substantial number of people who failed to return to the village. Also, there were those who simply disappeared, such as those who failed to pay debts.

Obviously, not all local authorities removed the names of those people automatically. In some cases, which Akira Hayami calls registers 'compiled on the current domicile principle', those people were just tagged or appended, so that the village's de facto population can be reckoned separately from its de jure population. ${ }^{27}$ A village of Mino province called Nishijo was one such case, where each household was appended with a section in which household members who had left the household to work elsewhere or to get married out. Although the date of moving-out is not given there, the section (called sotogaki, literally outside section) lists all those who moved out elsewhere and still stayed away. ${ }^{28}$ Similar lists are said to have been compiled in many places and called differently; in Hitachi province's Ibaraki district, for example, it was called a sage ninbetsu-cho (appended register) ${ }^{29}$ In other cases, the village authorities compiled a separate register for those who were supposed to be other provinces, listing not just 'absconders' but temporal out-migrants as well. ${ }^{30}$ All these examples may be taken to suggest that the village authorities tried to come to terms with the reality of out-migration. However, given the general custom quoted above, many must have become registerless eventually, and as contemporaries thought, most of the registerless drifted towards towns and cities. One historian speculates, based on a remark by one overlord at the time of the Tenmei famine in the late eighteenth century, that with both types of the registerless together they could have amounted to one million, which is probably an overestimate. ${ }^{31}$

Finally, a few words are necessary for non-commoner populations. The ruling class of samurai are said to have been covered by religious surveys but their registers were never compiled. ${ }^{32}$ On the other hand, the outcasts were all registered but separately from the commoners. The 1880

\footnotetext{
${ }^{26}$ Wigmore, Law and justice, pt vii, p.134.

${ }^{27}$ Cornell and Hayami, 'Shūmon aratame chō', pp.171-173; 'Hayami, Historical demography, pp.28-31.

${ }^{28}$ Table 4 below. See Saito and Hamano, 'Death of the partner', p.164, on practice in the Nishijo village. For another example, see Cornell and Hayami, figures 10.3-10.4 on pp.171-172.

${ }^{29}$ Wigmore, Law and justice, pt vii, pp.139, 216.

${ }^{30}$ This is what village officials in Tōtōmi province's Sano district were doing. See Wigmore, Law and justice, pt vii, p.137.

${ }^{31}$ Sekiyama, Kinsei Nihon, pp.57, 155. The total population is estimated to have been about 31 million.

${ }^{32}$ Sekiyama, Kinsei Nihon, pp.89-90.
} 
ruish $\bar{u}$ makes it clear that they were 'registered separately, and the temple register of each [category of the outcasts] is filed at the feudal office', ${ }^{33}$ thus suggesting that Tokugawa Japan's civil registration was to cover the ruled but not the ruling elite.

\section{The Meiji registration system}

The Tokugawa regime collapsed in 1868. While it took the form of a restoration of imperial rule, the pressing need for the 'Restoration' forces was how to build a new nation-state. Before the new government were two sets of competing models of state formation. One was a centuries-old Chinese typology in government: central, bureaucratic rule (gunken) versus decentralised, feudal divisions (hōken). Since the Tokugawa regime was considered a typical example of the latter model, the new Meiji government opted for the former, which meant the increasing centralisation of all systems. The other set concerned the balance between nationalism and Western influences. After the opening of the country in 1859 there was an influx of Western learning and ideas, giving rise to a period of 'civilisation and enlightenment' (bunmei kaika). Many of the themes of the Japanese enlightenment were instrumental in nation building, but at the same time the proWestern arguments alarmed conservatives. Thus, the state had to make a delicate choice in many areas of institutional reform attempts. The registration of family and land was one such area.

\section{Household registration}

A new system of household registration was introduced in 1872. When promulgated, it was proudly proclaimed in the Preamble to this first Family Registration Law that: 'Any government's first and most important task is to clarify the count of households and the number of population. There is no need to be said that the protection of people of the nation is the primary objective of this Sovereign State. Without the count of people to be protected, how could the protective duties be provided?' ${ }^{34}$ The language used sounds Confucian: it probably meant to appeal to the Confucian sentiment of benevolence, not to any version of modern welfare statism. It is therefore difficult to know what kind of 'protective duties' the government actually thought of. On the other hand, there is evidence that the new government faced a 'law and order' problem in the Capital; as soon as the civil war with the Tokugawa and its Allies was over, a large number of masterless samurai flowed into the metropolitan areas. Decrees and notices issued by a newly

\footnotetext{
${ }^{33}$ Wigmore, Law and justice, pt vii, p.3. See also Sekiyama, Kinsei Nihon, pp. 90-92. The author notes that although in some provinces they may not have been included in population totals, individually they were all registered.

${ }^{34}$ Dajōkan fukoku, no. 170 (1871).
} 
created Council prior to the promulgation of the Family Registration Law often mentioned the rampages of unregistered, penniless ex-samurai in Tokyo, relating this issue to the urgency of tighter registration. ${ }^{35}$ Whatever the ulterior motif of this writing was, however, the Preamble to the 1872 law does suggest that the new government was committed to create a comprehensive system of registration.

The abolition of the decentralised domainal governance structure in the previous year paved the way to a centralised institution-building in the area of population accounting, and an important departure from the Tokugawa past was made to bring all social classes (except the Royal Family) in every region of the country under a unified framework. Across the country was used a standardised identity register. The entries in this 1872 register format were: address, ownership of the house, status distinction (aristocracy, ex-samurai, commoner, or new commoner), occupation, headship and the relation to the head, birth year, and age; for adopted or married-in members of the household, the address of the former residence, status, and the parents' names and status were also required to enter-all registered with surnames. It was much more detailed than in the Tokugawa register, although its entries were a little simplified later, as shown in figure $2 .{ }^{36}$ Whichever, it is important to realise that for the first time the ruling elite were treated equally with the ruled. Also, upon the Edict of Emancipation in 1871 the former outcasts were integrated into the commoner class, although as a matter of fact the added adjective 'new' in the 1872 register made their emancipation only nominal (discrimination against the former outcasts may well have increased rather than decreased). ${ }^{37}$ It is believed that actual methods of recording and monitoring at the local level remained largely the same as in Tokugawa times. It was also required to take a comprehensive survey of population and households once in every six years, which had been another aspect of the Tokugawa-Meiji continuity. ${ }^{38}$

\section{[Table 2]}

Meiji Japan's civil code, which came into effect in 1898, is known for its unusually strong emphasis on the authority of the family head in its private law areas. Indeed, the adopted version was a product of a long, politicised discussion. An earlier draft in 1890, based largely on an

\footnotetext{
${ }^{35}$ Gyōseikan futatsu, nos. 261, 267, 323 and 358 (1869). The Gyōseikan (Executive Council) was replaced by the Dajōkan (Grand Council of State) in July 1869.

${ }^{36}$ A similar model register is tabulated in Winther, 'Household enumeration', p.28. However, it is a form attached to an 1875 draft for the revision of family registration procedures, which did not materialise.

${ }^{37}$ The 1872 register was in use until post-war years. It was as late as 1968 when it was officially closed.

${ }^{38}$ Sato, Kokusei chōsa, pp.45-49.
} 
individualist French model, was criticised by conservative scholars as well as politicians, who argued that its adoption would destroy traditional family values as the draft did not make enough provisions for the head of the family: one spokesman of the school blasted it by saying that 'Loyalty and filial piety will perish with the enactment of the civil code'. It was a version revised substantially along this conservative line that was enacted eventually. ${ }^{39}$ The revision was most marked in the area of family law. Thus, according to the 1898 civil code, members of the family household or 'house' (ie) were subject to the authority of the head. Daughters-in-law and adopted children entered an ie and, hence, were registered as such only with the consent of its head (article 750). The head could even determine a member's place of residence in so far as such an action was considered necessary for the family (article 749). The primacy of the household head was firmly established by the 1898 civil code, ${ }^{40}$ although, as we will see below, it is important to realise that in areas other than family law, especially in property law, much of the individualist principle inherent in the draft code was retained.

The Family Registration Law, revised at the time of the enactment of the 1898 civil code, did not alter the 1872 procedures greatly. However, its administration was transferred to the Ministry of Justice from the Home Ministry (to which the Statistical Bureau belonged). With this change, a couple of small but important modifications were made. One was the exclusion of occupation from the entries in the registration form. Another is that the idea of census taking through registration data was abandoned, which became a separate agenda leading to the implementation by the Statistical Bureau of the first national census in 1920. Both may be taken to suggest that, under the 1898 regime, household registration was placed in the field of 'law and order', rather than that of 'population and statistics', making it clear that the central state was now fully prepared to deal with criminality on the one hand and local disputes over inheritance and privileges on the other. ${ }^{41}$

\section{Land registration}

In the year 1872 another important change was made with respect to the registration question. A certificate of ownership (chiken) was issued to the holder of any parcel of land in the country, on which the name and address of the holder, the location, category and area of the parcel, and also

\footnotetext{
${ }^{39}$ For a brief account of the debate, see Frank et al., 'Civil code', sec 3.1, and Hirakawa, 'Japan's turn', pp.472-479.

${ }^{40}$ For an exposition of this aspect of family law in the Meiji civil code, see de Becker, Principles and practice, pp.647-654, and Frank et al., 'Civil code', pp.283-285.

${ }^{41}$ Sato, Kokusei chōsa, p.51, n.9.
} 
its monetary value were indicated. Figure 3 shows that the certificate was signed by the governor of a prefecture with his seal also affixed. The original was kept by the landholder himself and the copy filed at the prefectural office. With the issue of such certificates, therefore, the ownership of land property in the modern sense was formally established. In the next year the government announced a radical revision of taxation on land; the 1872 certificate was to be substituted by a new one in the course of the land tax reform, although it took several years to complete the whole process. When the owner sold a parcel of land to someone else, the transfer was endorsed at the local government office where the name and address of a new owner were added on the back of the certificate. Clearly this ownership certificate, especially its copy kept by the prefectural office, served also as a register document, replacing the age-old framework based on cadastral surveys. This registration mode lasted until 1889 when a new type of the land register was re-introduced, although the principal features of the registration system remained the same.

One crucial but probably unintended consequence of the whole reform was that the village community no longer mattered: village administration lost their discretionary power to influence market transactions in land. Together with this new registration framework came a western, centralised court system. The whole system enabled anyone to buy and sell a parcel of land across the administrative boundaries and, if the client failed to keep his promise, to take the case to court. The reason why the government underwent such a radical land reform was fiscal, to secure a stable source of tax revenue. In so doing, however, they brought in two important changes. First, the state formally granted the peasant landholder the title to that land. Second, the land tax was now to be paid in cash, not in kind. This monetisation drive, together with the confirmation of absolute private ownership, enabled transactions in land taking place more openly and frequently. The certificates thus functioned as marketable securities in the age of market expansion.

\section{[Table 3]}

Given the significance of the land-family bond in the Tokugawa period, it is interesting to see if the primacy of the family head, identified in the registration of a household and its members, was also expressed in the above mode of land registration. Recently Jennifer Winther has argued in her article on the evolution of household enumeration that 'Under the Meiji civil code that governed the household registers, wives, concubines, children, siblings, parents, extended or adopted family, and servants were enumerated as members of the head's household, but like 
livestock, land, and inanimate objects, they were bound to the head legally as his property'. ${ }^{42}$ The statement is strong but metaphorical. Even so, what is suggested is that the head's authority extended to landed property, which is misleading. Indeed, a cursory look at the form of the certificate of ownership (see table 3 ) reveals that there was no sign of familial information on either side of the document. It is also clear from the corresponding provisions of the 1898 civil code that an individual family member was allowed to own separate property in his or her own name (article 748). In other words, on the death of the family head, the property right of the family land could be passed on separately from that of the headship. Given the weight of this legal evidence, therefore, it is wrong to conclude that both were centred on the corporate family household (ie): household registration was based on the ie concept, but land registration was not. As Joseph de Becker noted in 1921, 'the idea of property belonging to a house [ie] itself, and the head of the house being merely the manager thereof, is now obsolete from the legal point of view at least, although it must be conceded that many an old-fashioned and conscientious head of a house is still governed by that idea'. ${ }^{43}$ Legally speaking, the Tokugawa concept of family property and the idea of the head 'being merely the manager thereof' gave way to the ones based on a more individualist principle. Apparently, under the new Meiji regime, power relationships within the family changed. Headship was strengthened in both legal and economic-financial terms, enabling the family property more secured as long as the head remained risk-averse, but, paradoxically, much less so whenever he ventured to take a risk in a newly opened-up business world.

\section{Tokugawa-Meiji comparisons}

Having surveyed the evolution of registration systems in Japan from the seventeenth to the nineteenth century, one may ask whether or not progress in terms of civil identity registration was actually made in the Tokugawa-Meiji transition and, if any, then what sort of progress it could be.

Let us first examine the role of the family head in registration procedures. Here the yardstick cannot be the dichotomy of corporate versus individualist principle as in both Tokugawa and Meiji times the mode of registration was centred on the family household, not on the individual. A more realistic distinction is probably between management by face-to-face contacts and management by written documents. Although the degree to which written documentation played a

\footnotetext{
${ }^{42}$ Winther, 'Household enumeration', p.27.

${ }^{43}$ de Becker, Principles and practice, p.637.
} 
role in Tokugawa village society should not be underestimated, ${ }^{44}$ the early Meiji period did see a decisive shift taking place from the former to the latter mode of management. ${ }^{45}$ In this respect, it is worth reiterating that in the Tokugawa register the headship was assumed, whereas under the Meiji civil code the head was a legally recognised status. In both Tokugawa and Meiji times, it is likely that people's perception of the family and their expectation about the role of the head remained virtually unchanged. Under traditional Japan's stem family system, one child stayed on in the household, who would succeed both headship and family property from the father. The child could be the eldest son, the youngest son, or even a daughter who would adopt a husbandin-law. When demographic events disrupted this procedure, a person with whom everybody in his or her kin group could agree would be chosen as a person suitable to look after the maintenance of family welfare and continuation. In almost all cases, probably, such tacit rules would bear no problem. However, there were always exceptional cases where one's expectation deferred sharply from the other party's in that kin group, which would lead to a family dispute, or as in Ken's story, even to litigation. If who was the family head was an issue, things would be extremely difficult to solve - as far as the Tokugawa society is concerned. Yet, in the Meiji world of management by written documents, its consequence could be different. The Meiji civil code was specific enough to appoint someone in the family as the head even when a prospective heir son was absent. ${ }^{46}$ The name on the document kept in the state office was the head of the family household, however its actual boundary or structure was difficult to define. Moreover, as emphasised above, registration of landed property was made on an individualist principle even in the Meiji regime. This gap between the two registration principles could be another source of dispute, if the ownership of a piece of land was involved in that conflict. According to the Meiji legal framework, however, the name on the document was the owner of the real estate in question, whatever other kin people had said about his legitimacy as a genuine occupier of the land. To borrow the phrase used by de Becker, the head was no longer a mere 'manager' of family property. ${ }^{47}$ All this, it is believed, could act against the interests of women in the family, since Meiji Japan's family law was patriarchal, reflecting much of Tokugawa-era samurai ideology but somewhat different from peasant-class practice. Apparently the early Meiji period saw male authority strengthened in the form of headship functions. It is difficult to say therefore that, in terms of gender equality in 'protection' by the state, much progress was made between the two regimes.

\footnotetext{
${ }^{44}$ Ooms, Tokugawa village practice, pp.69-70.

${ }^{45}$ For the prevalence of tacit agreement between peasant transactions, see Sato, 'Meiji “kindai" hōsei'.

${ }^{46}$ Frank et al., 'Civil code', p.316.

${ }^{47}$ See n. 42 above.
} 
The second area is that of vital registration. As we have seen, there was a tendency that in Tokugawa times babies were not immediately registered, as a result of which those who died young may not have been recorded in the death register, either. It is likely that such customs survived well into early Meiji years. For example, even a doctor did not bother about writing a death certificate for those who died before three months of age. However, such underenumerations are said to have declined substantially by 1890 . In 1880 procedures for the notification of infectious diseases were formalised, and in 1884 a certificate of death by the medical practitioner became compulsory for the burial, both of which are believed to have been effective to reduce the numbers of unreported births and deaths. ${ }^{48}$

The third area to be examined is the question of disowning. As we have seen, the right by the head's or parents to disown a child could result for the disowned in a loss of any protection from the community in the Tokugawa past. However, this concept of disowning cannot be found in provisions of the Meiji civil code. One may argue that the possibility of a prospective heir losing his right of inheritance (article 891) and the head's aforementioned right to determine one's place of residence (article 749) could be interpreted as legacies from Tokugawa practice. However, they should be seen as disinheritance, not of disowning practice. Apparently the concept of disowning was abandoned by Meiji law experts.

One implication of this decision was that the disinherited would no longer become registerless for that reason. However, there still existed other factors that accounted for much of registerlessness in the Tokugawa period, especially out-migration. The fourth area is concerned with this question of how to register people who left the native village for a substantial period of time. After the Meiji reforms, their numbers were on the increase. A solution sought for by the Meiji government was the introduction of a concept of 'staying temporarily' (kiryū). Under a new framework, a person who stayed in a place other than his or her de jure domicile (honseki) for more than 90 days was described as in kiry $\bar{u}{ }^{49}$ Although one could move the de jure domicile, it was usually in the place where the ie, the family household he or she belonged to, was registered. According to regulations brought in with this concept, any person who would like to move the residence out of his or her de jure domicile was required to notify the village office for outmigration and also to notify the office of a place he or she was moving in. In the two offices, $k i r y \bar{u}$ registers were compiled, one was an out-kiry $\bar{u}$ register and the other an in-kiry $\bar{u}$ register.

\footnotetext{
${ }^{48}$ Takase, 'Jinkō dōtai to jinkō seitai', and Saito, 'Nyū-taiji shibō', pp.115-117.

${ }^{49}$ This was defined in the Kiry $\bar{u}$ Act enacted in 1915. However, the earliest usage of that concept can be found in Dajōkan fukoku, no.170, 1871.
} 


\section{[Table 4]}

The term kiry $\bar{u}$ was new, but the idea was not. It can be traced back to appended registers of outmigrants that some of Tokugawa villages devised. Table 4 is one such example, appended in an 'outside section' of one household's shümon register. There are altogether four people who had moved out from this household by the year of compilation, two were out working elsewhere and the other two married out. The latter are just for administrative record, but the former can be crucially important in the sense that if their names had completely been removed from the register, and if they had failed to register in their new places, they would have been registerless. The Meiji system incorporated this element, making compulsory for the migrant to notify not only the village office but the town office as well and for both offices to keep the records. This incorporation was made probably for 'law and order' reasons, not as a protective measure. Whatever the reason, however, the consequence was that no one could in theory be administratively invisible. (After World War II this registration framework was abolished, giving way to a new residency registration arrangement. Under the post-war system almost all entitlements the citizen can claim are linked to the current residence, although duality with de jure registration is still being kept.)

The system was far from perfect, however. Some of the migrants were extremely mobile. For anyone coming from the countryside to Tokyo in search of employment, it is likely that he filled in the form at both village and town-ward offices, as an out-migrant in the village and as an inmigrant in a Tokyo ward. Probably he changed the residence frequently within the metropolitan city until he finally settled down where he would probably register again as in-migrant in a new ward without submitting a notification of leave to the previous ward. This double-registration would not matter for him as long as he could find a job. But for population accounting, it caused a serious problem. Because of such double counting of in-migrants, Tokyo's currently resident population in 1910 is said to have been in excess of 700,000 when its actual population was 2 million, reinforcing doubts about household registration information as population data and making the case for census taking even stronger. ${ }^{50}$

Another problem was whereabouts of those migrants who were stranded in an anonymous urban world. Being solitary in an urban environment was, as suggested in a 1923-26 survey of the poor initiated by the city of Osaka, a forerunner in the history of Japan's welfare administration, 'the principal cause of poverty'. The problem was particularly serious for the elderly poor. Indeed, of

${ }^{50}$ Sato, Kokusei chōsa, pp.48-50 
those seeking welfare assistance in Osaka 34 per cent was 60 years of age or older as compared with 12 per cent for under-15-year-olds; and the proportion solitary increased from 59 per cent in the age group of 15-59 to 80 per cent in that of 60-plus. ${ }^{51}$ We do not know how many of the solitary poor in Osaka were those who had eventually lost contact with their families in the native village, but it is likely that in a substantial number of cases their ties must have long since been cut off. And if those elderly people moved from a slum to another slum in the city, and if they lost interest in registering themselves in a new place, then they would easily been stranded and become invisible administratively.

That said, however, it should be recognised that, compared with Tokugawa practice in this respect, the new Meiji system succeeded in reducing registerlessness drastically, which may have had significant implications for town-ward migrants. It must have also been important in order to cope with the problem of child labour in an age in which industrialism was advancing while the state's provision for areas such as schooling was expanding. ${ }^{52}$

\section{Epilogue}

By way of concluding our account of the evolution of registration systems in eighteenth- and nineteenth-century Japan, we take a brief look at another village dispute that took place in $1880 .{ }^{53}$ It was a court case initiated by a middle-aged peasant woman named Masata Hagiwara on 2 September that year. She demanded for the return of a certificate of land ownership.

The centre stage was Kanai village of Kanagawa prefecture, some $20 \mathrm{~km}$ north of the Treaty port of Yokohama, and the lawsuit was against the village headman, accusing him of mal-practice in administrative procedures. However, the real dispute was with her younger brother Rokuemon, who is said to have indulged in drinking and gambling. Masata was unmarried; she had been in service for about 30 years, but returned to the village when Rokuemon, who had already succeeded both headship and ownership of the family land from his father, left for Yokohama. Since then she looked after her retired father and helped him working the land. Rokuemon was unsettling. In 1877, soon after Rokuemon left the house, she went to the office to report her brother's 'disappearance' (shissō), in which she requested the headman to allow the Hagiwara

\footnotetext{
${ }^{51}$ See Tamai, 'Images of the poor', pp.107-109.

${ }^{52}$ For relationships between child labour and education, see Saito, 'Children's work'. It is worth noting that there emerged a number of night classes, Sunday schools and childminders' classes for children sent away from home to work in towns and cities, for which their registration must have been crucial (pp.471-472). ${ }^{53}$ The following account draws on Sato, 'Meiji "kindai" hōsei', which is based largely on Kusanagi mss in the Machida Archive, Tokyo. The village headman sued by Masata was from the Kusanagi family.
} 
family to disown Rokuemon and to remove his name from the register. Her argument was that she was entitled to do so on behalf of her father because it was she who was keeping the family economy going and looking after the ageing father, which, according to her understanding, meant that Rokuemon, who had abandoned the family household's business and was not living with the parent and other members of the household, could no longer be a head of the Hagiwara family. The request was not accepted simply because there was no place for formal disowning procedures within the framework of Meiji family law.

Also in dispute was the family land. In 1878 when Rokuemon left the Kanai village for Yokohama by filling in the kiryu form of leaving-out, he borrowed 400 yen, presumably as startup capital for his business, on the land in the Kanai village. Precisely speaking, he borrowed money by 'placing the land in pawn' (shichiire). Under this type of contract, the ownership was transferred to the lender but the occupier was allowed to till the land by paying the rent; in this particular case, the occupier was Masata, not Rokuemon. As a result, she came to know her brother's financial venture. In order to keep the land in the family, she managed to raise the money and took its ownership back (and this was another reason for her to argue that her brother could not claim his family headship). During this period, the original certificate of ownership of the Hagiwaras' land, issued in 1872, had always been in Masata's hands. However, the land tax reform that started in 1873 required the 1872 certificate to be substituted for by a new one; and as the complete substitution would take some time, village administration was allowed to handle cases of change in ownership without the 1872 certificate submitted in. Rokuemon took advantage of this transitional measure; he sold the land off without letting her sister know about his transaction. She thus accused the headman of the ways in which he handled the case of that land transaction.

Not surprisingly the decisions at the court in Yokohama and the Tokyo court of appeal were not in favour of Masata's. To quote the latter's decision, 'Rokuemon, in his capacity of the head of the household, liquidated his own property and made a transfer [of its ownership], an action in which another person cannot interfere'; by 'another person', of course, the judge meant the village headman whom Masata accused in her lawsuit. If it had been in Tokugawa times, her arguments might have sounded somewhat more persuasive; any heir-son who was too unsettling to manage family business properly would not have been considered a head of the family. ${ }^{54}$

\footnotetext{
${ }^{54}$ In this respect, it is interesting to note that while Masata in her litigation document accused Rokuemon for having been 'prodigal' (hōtō) and 'unruly' (burai), two Kanai villagers described him with virtually the same words in their witness accounts.
} 
Within the Meiji regime of law and practice, however, her claim that she was the de facto head of the family became groundless under the new registration system. Moreover, both Rokuemon's sale of land and the headman's handling of the cases were perfectly lawful and their documents flawless. The Meiji reforms acted against her interests.

As for her brother, on the other hand, we do not know how he fared in the trading port of Yokohama, although it is not unlikely that he failed in business and eventually became penniless.

If it had been the case, it could have been he, or his impoverished family, who might have benefited from such reforms in identity registration. Given the underdevelopment of Meiji Japan's welfare provisions, however, it is not unlikely either that he might eventually be discovered dead in an anonymous urban world, just like some of present-day centenarians who had long since died having lost contact with their family. ${ }^{55}$

\footnotetext{
55 'Centenarians "missing” ahead of Japanese day honouring elderly', The Guardian, 12 August 2010. This news report is summarised as: 'Authorities admit privacy laws and antiquated registration systems mean 200 elderly people are unaccounted for'.
} 
References

Cornell, L.L., and A. Hayami, ‘The shūmon aratame chō: Japan's population registers', Journal of family history, vol.11, no.4 (1986); reprinted in A. Hayami, Population, family and society in pre-industrial Japan (Folkestone, Kent: Global Oriental, 2009), pp.165-184.

De Becker, J.E., The principles and practice of the civil code of Japan (London: Butterworth \& Co., 1921).

Dore, R.P., Education in Tokugawa Japan (Berkeley: University of California Press, 1965).

Frank, R., H.P. Marutschke and P. Schmidt, 'Civil code', in W. Röhl, ed., History of law in Japan since 1868 (Leiden: Brill, 2005), pp.166-329.

Hayami, A., The historical demography of pre-modern Japan (Tokyo: University of Tokyo Press, 2001).

Hirakawa, S., 'Japan's turn to the West', in M.B. Jansen, ed., The Cambridge history of Japan. Volume.5: The nineteenth century (Cambridge: Cambridge University Press, 1989), pp.432-498.

Moriya, K., 'Urban networks and information networks', in C. Nakane and S. Ōishi, eds, Tokugawa Japan: the social and economic antecedents of modern Japan (Tokyo: University of Tokyo Press, 1990), pp.97-123.

Ooms, H., Tokugawa village practice: class, status, power, law (Berkeley: University of California Press, 1996).

Ozaki Yukiya, 'Shinshū Saku-gun Makibuse-mura Kenjo ikken: kinsei nōson joseishi-ron to shite', Rekishi hyōron, no.149 (1985), pp.45-66.

Saito, O., 'Children's work, industrialism and the family economy in Japan, 1872-1926', in H. Cunningham and P.P. Viazzo, eds, Child labour in historical perspective, 1800-1985 (Florence: Unicef International Child Development Centre, 1996); reprinted in K. Lieten and E. van Nedereveen Meerkerk, eds, Child labour's global past (Amsterdam: International Institute of Social History, forthcoming), pp.457-477. 
Saito Osamu, 'Meiji-ki no nyū-taiji shibō: Kita-Tama nōson no ichi jirei', in Hayami Akira, ed., Kindai ikōki no jinkō to rekishi (Kyoto: Mineruva Shobō, 2002), pp.99-118.

Saito, O., 'Land, labour and market forces in Tokugawa Japan', Continuity and change, vol.24, issue 1 (2009), pp.169-196.

Saito, O., and K. Hamano, 'The death of the partner, remarriage and family continuation in Tokugawa Japan: a village study', Revista de demografía histórica, vol.24, no.2 (2006), pp.155-178.

Sato Masahiro, 'Meiji "kindai" hōsei no dōnyū to dentōteki kanshū-hō: kasan shoyū to kachō-ken no jirei kenkyū', Shakai keizaishigaku, vol.50, no.5 (1885), pp.585-604.

Sato Masahiro, Kokusei chōsa to Nihon kindai (Tokyo: Iwanami Shoten, 2002).

Sato, T., 'Tokugawa villages and agriculture', in C. Nakane and S. Ōishi, eds, Tokugawa Japan: the social and economic antecedents of modern Japan (Tokyo: University of Tokyo Press, 1990), pp.37-80.

Sekiyama Naotaro, Kinsei Nihon no jinkō kōzō: Tokugawa jidai no jinkō chōsa to jinkō jōtai ni kansuru kenkyū (Tokyo: Yoshikawa Kōbunkan, 1958).

Takase Masato, '1890-1920 nen no waga kuni no Jinkō dōtai to jinkō seitai’, Jinkōgaku Kenkyū, no.14 (1991), pp.21-34.

Tamai, K., 'Images of the poor in an official survey of Osaka, 1923-1926', Continuity and change, vol.15, issue 1 (2000), pp.99-116.

Totman, C., Early modern Japan (Berkeley: University of California Press, 1993).

Walthall, A., 'The life cycle of farm women in Tokugawa Japan', in G.L. Bernstein, ed., Recreating Japanese women, 1600-1945 (Berkeley: University of California Press, 1991), pp.42-70.

Wigmore, J.H., ed., Law and justice in Tokugawa Japan. Materials for the history of Japanese law and justice under the Tokugawa shogunate 1603-1867, 16 vols (Tokyo: University of Tokyo Press, 1967-86). 
Winther, J.A., 'Household enumeration in national discourse: three moments in modern Japanese history', Social science history, vol.32, no.1 (2008), pp.19-46. 
Table 1. A sample page from a shümon aratame register

\begin{tabular}{|l|c|l|c|}
\hline One household & Age & $\begin{array}{l}\text { Address and } \\
\text { NAME of temple, denomination }\end{array}$ & {$[$ Seal] } \\
\hline NAME & Age & $\begin{array}{l}\text { Address and } \\
\text { NAME of temple, denomination }\end{array}$ & {$[$ Seal] } \\
\hline Daughter NAME & Age & $\begin{array}{l}\text { Address and } \\
\text { NAME of temple, denomination }\end{array}$ & {$[$ Seal] } \\
\hline Son NAME & Age & $\begin{array}{l}\text { Address and } \\
\text { NAME of temple, denomination }\end{array}$ & {$[$ Seal] } \\
\hline Daughter NAME & Age & $\begin{array}{l}\text { Address and } \\
\text { NAME of temple, denomination }\end{array}$ \\
\hline Son NAME & Age & $\begin{array}{l}\text { Address and } \\
\text { NAME of temple, denomination }\end{array}$ & {$[$ Seal $]$} \\
\hline \multicolumn{2}{|c|}{ Total [ ] } & $\begin{array}{l}\text { Of which Males [ ] } \\
\text { Females [ ] }\end{array}$ \\
\hline
\end{tabular}

Source: Hayami, Historical demography, p.29; from the 1773 register, Kōmi village, Motosugun, Mino province.

Note 1) The name and seal at the top of page are those of the head of the list.

2) The name of wife is not given.

3) The seal affixed at the end of each individual entry is that of a temple. 
Table 2. Meiji household registration format

\begin{tabular}{|c|c|c|}
\hline \multicolumn{3}{|l|}{ Date } \\
\hline \multicolumn{3}{|c|}{$\begin{array}{l}\text { Address } \\
\text { Status } \\
\text { Former head NAME }\end{array}$} \\
\hline \multicolumn{3}{|c|}{ Date of succession of headship } \\
\hline & Head & $\begin{array}{l}\text { NAME [Eldest] son of former head NAME } \\
\text { Date of birth }\end{array}$ \\
\hline \multicolumn{3}{|c|}{ Date of marriage-in [Second] daughter of NAME, status, address } \\
\hline & Mother & $\begin{array}{l}\text { NAME Wife of former head } \\
\text { Date of birth }\end{array}$ \\
\hline \multicolumn{3}{|c|}{ Date of marriage-in [Third] daughter of NAME, status, address } \\
\hline & Wife & $\begin{array}{l}\text { NAME } \\
\text { Date of birth }\end{array}$ \\
\hline & Eldest son & $\begin{array}{l}\text { NAME } \\
\text { Date of birth }\end{array}$ \\
\hline & $\begin{array}{l}\text { Eldest } \\
\text { daughter }\end{array}$ & $\begin{array}{l}\text { NAME } \\
\text { Date of birth }\end{array}$ \\
\hline & Second son & $\begin{array}{l}\text { NAME } \\
\text { Date of birth }\end{array}$ \\
\hline
\end{tabular}

Note: 1986 format adopted by the Home Ministry. 
Table 3. Certificate of land ownership

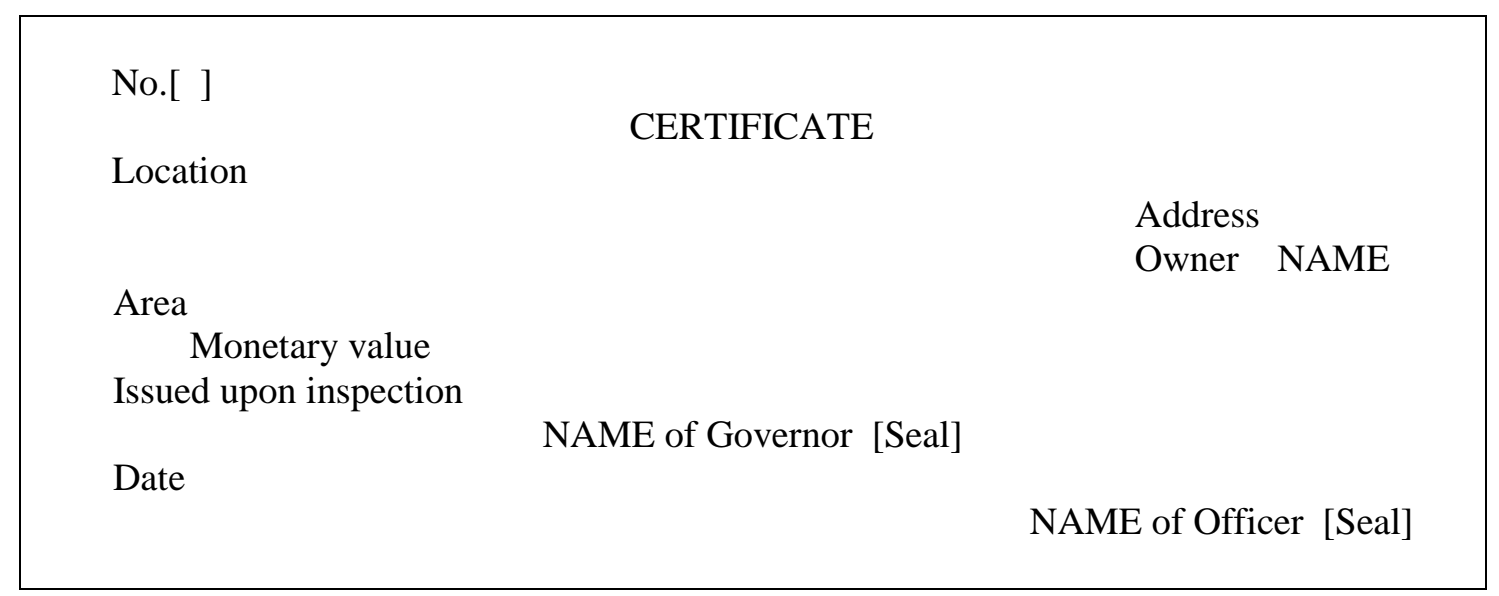

Source: An 1873 certificate issued by Akita prefecture (http://www.daito.ac.jp/ mnoguchi/tanto_kougi/kougi_fudosan/fudosan_chiken.htm). 
Table 4. An appended outside section (sotogaki) of shümon aratame register

\begin{tabular}{|l|l|l|}
\hline \multicolumn{2}{|l|}{ Soto (Outside section) } \\
\hline One person & Working in PLACE NAME & Daughter NAME, age \\
\hline One person & Working for samurai household in PLACE NAME & Daughter NAME, age \\
\hline One person & Married to NAME, address & Daughter NAME, age \\
\hline One person & Married to NAME, address & Sister NAME, age \\
\hline
\end{tabular}

Source: Hayami, Historical demography, p.31. Appended to a family household headed by a 65-year-old peasant, Nishijo village, Ampachi-gun, Mino province, 1804.

Note: No date of moving-out is recorded in this section of the register. 